\title{
PLASMA LEVELS AND CARDIOVASCULAR EFFECTS OF NITROGLYCERIN IN PREGNANT SHEEP
}

\author{
M. de Rosayro, M.L. Nahrwold, A.B. Hill, A.R. TAit, M.D. Taylor Busch and M.M. Kirsh
}

\section{ABSTRACT}

The cardiovascular effects and blood levels of intravenous nitroglycerin in mother and foetus were studied in normotensive and hypertensive ewes. Although nitroglycerin produced a reduction in uterine blood flow following a decrease in blood pressure, there was little if any incidence of adverse effects in the foetus. Nitroglycerin was detected in all but two samples of foetal arterial blood but the foetal/maternal artery ratio was only 0.04 . Nitroglycerin merits further evaluation for the treatment of acute hypertensive episodes in the preeclamptic patient.

THE MANagement of the moderate to severe preeclamptic patient aims at preventing convulsions and controlling hypertension, the only definitive therapy being delivery of the baby. Convulsions can usually be prevented by magnesium sulphate or by heavy sedation with chloromethiazole or diazepam. The methods of controlling hypertension remain controversial, even though the main cause of maternal mortality in these patients is cerebral haemorrhage. Severe hypertension is also associated with left ventricular failure, renal impairment, and disseminated intravascular coagulation.

Hypertensive patients have been shown to exhibit marked cardiovascular reflexes in response to laryngoscopy and intubation, resulting in acute hypertensive crises. ${ }^{1}$ Preeclamptic patients undergoing general anaesthesia may be even more at risk during this period due to the light level of anaesthesia usually employed before delivery of the baby. The ideal antihypertensive agent to prevent this response would act rapidly and predictably, have a short duration, and be of low toxicity to both mother and baby. The drugs most commonly used in this situation are hydralazine and diazoxide. Intravenous hydralazine has an onset of action of up to 20 minutes, and its duration of action varies from two to three hours. Toxic effects are common and may mimic the symptoms of impending eclampsia (headaches, tremors, nausea and vomiting). Diazoxide has a

M. de Rosayro, F.F.A.R.C.S., Assistant Professor of Anesthesiology; M.L. Nahrwold, M.D., Associate Professor of Anesthesiology; A.B. Hill, F.F.A.R.C.S., Assistant Professor of Anesthesiology; A.R. Tait, B.Sc., Research Associate, Anesthesiology; M.D. Taylor Busch, B.S., Research Associate, Anesthesiology; M.M. Kirsh, M.D., Professor of Surgery. The University of Michigan, Ann Arbor, Michigan 48109.

Address reprint requests to $\mathrm{Dr}$. de Rosayro. more rapid onset but has a long duration ranging from four to twelve hours. Placental transfer of diazoxide has been reported in sheep ${ }^{2}$ and its side effects include hyperglycaemia, decreased uric acid excretion, neutropaenia, and thrombacytopaenia. $^{3}$

Recently, intravenous nitroglycerin has been used successfully to control hypertension during coronary artery surgery ${ }^{4}$ and to induce hypotension for neurosurgery. ${ }^{5}$ It may, therefore, be a useful agent in the management of the preeclamptic patient prior to and during general anaesthesia. Accordingly, we investigated the ability of nitroglycerin to cross the placenta as well as its cardiovascular effects in both normotensive and hypertensive pregnant ewes.

\section{Methods and Materials}

Six pregnant ewes at $120-130$ days gestation (term $=150$ days) underwent induction of anaesthesia with methoxyflurane in oxygen. Following tracheal intubation, a paralyzing dose of pancuronium was used and anaesthesia was maintained with intravenous ketamine given in $25 \mathrm{mg}$ increments. Ventilation was controlled using a Harvard animal pump to maintain $\mathrm{Pa}_{\mathrm{CO}_{2}}$ near normal. $\mathrm{Pa}_{\mathrm{O}_{2}}$ was maintained around $13.3 \mathrm{kPa}$ by the addition of oxygen to the inspired air. The following vessels were cannulated: maternal femoral artery and vein, maternal jugular vein and foetal femoral artery. An electromagnetic flow probe (Carolina Medical Electronics) was placed around a main branch of the uterine artery. Maternal and foetal arterial blood pressures, maternal electrocardiogram, heart rate and uterine blood flow were recorded continuously on a Gould 2600 Recorder (Gould Instruments). 
TABLE I

Maternal Parameters following Nitroglycerin Infusion in Normotensive Ewes (Means \pm SEM)

\begin{tabular}{|c|c|c|}
\hline & Control & After nitroglycerin \\
\hline Systolic blood pressure - $\mathrm{kPa}(\mathrm{mm} \mathrm{Hg})$ & $17.24 \pm 0.45(130 \pm 3.4)$ & $12.37 \pm 0.92^{*}\left(93 \pm 6.9^{*}\right)$ \\
\hline Diastolic blood pressure $-\mathrm{kPa}(\mathrm{mm} \mathrm{Hg})$ & $11.31 \pm 0.43(85 \pm 3.2)$ & $7.58 \pm 0.52^{*}\left(57 \pm 3.9^{*}\right)$ \\
\hline Mean blood pressure - $\mathrm{kPa}(\mathrm{mm} \mathrm{Hg})$ & $13.57-0.27(102 \pm 2.0)$ & $9.31 \pm 0.4^{*}\left(70 \pm 3^{*}\right)$ \\
\hline Heart rate (beats/min) & $136 \pm 19$ & $159 \pm 16$ \\
\hline Uterine blood flow ( $\mathrm{ml} / \mathrm{min}$ ) & $370 \pm 62$ & $215 \pm 62^{*}$ \\
\hline $\mathrm{cH}^{+} \mathrm{nmal} / 1(\mathrm{pH})$ & $51.29 \pm 4.73(7.29 \pm 0.02)$ & $53.70 \pm 5.94(7.27 \pm 0.02)$ \\
\hline $\mathrm{Pa}_{\mathrm{CO}_{2}}-\mathrm{kPa}(\mathrm{mm} \mathrm{Hg})$ & $4.8 \pm 0.4(36.1 \pm 3.0)$ & $4.8 \pm 0.4(36.1 \pm 3.0)$ \\
\hline $\begin{array}{l}\mathrm{Pa}_{\mathrm{O}_{2}}-\mathrm{kPa}(\mathrm{mm} \mathrm{Hg}) \\
\text { Base excess }(\mathrm{mmol} / \mathrm{l})\end{array}$ & $\begin{aligned} 14.4 \pm & 1.06(108.3 \pm 7.9) \\
& -7.6 \pm 1.9\end{aligned}$ & $\begin{array}{c}11.6 \pm 0.8^{*}\left(87.2 \pm 6.0^{*}\right) \\
-9.4 \pm 1.7\end{array}$ \\
\hline
\end{tabular}

*p $<0.05$ compared to control.

TABLE II

Foetal Parameters Following Nitroglycerin lnfusion in Normotensive Ewes (Means \pm SEM)

\begin{tabular}{|c|c|c|}
\hline & Control & After nitroglycerin \\
\hline Systolic blood pressure - $\mathrm{kPa}(\mathrm{mm} \mathrm{Hg})$ & $8.65 \pm 0.28(65 \pm 2.1)$ & $8.25 \pm 0.78(62 \pm 5.9)$ \\
\hline Diastolic blood pressure - $\mathrm{kPa}(\mathrm{mm} \mathrm{Hg})$ & $5.72 \pm 0.45(43 \pm 3.4)$ & $5.72 \pm 0.41(43 \pm 3.1)$ \\
\hline Mean blood pressure - $\mathrm{kPa}(\mathrm{mm} \mathrm{Hg})$ & $6.92 \pm 0.40(52 \pm 3.0)$ & $6.78 \pm 0.53(51 \pm 4)$ \\
\hline Heart rate (beats/min) & $505 \pm 164 \pm 7$ & $\begin{array}{c}174 \pm 39 \\
54.95 \pm 2.53(7.26 \pm 0.02)\end{array}$ \\
\hline $\begin{array}{l}\mathrm{cH}^{+} \mathrm{nmol} / \mathrm{l}(\mathrm{pH}) \\
\mathrm{Pa}_{\mathrm{co}}-\mathrm{kPa}(\mathrm{mm} \mathrm{Hg})\end{array}$ & $\begin{array}{c}54.95 \pm 2.53(7.26 \pm 0.02) \\
6.7 \pm 0.4(50 \pm 3)\end{array}$ & $\begin{array}{c}54.95 \pm 2.53(7.26 \pm 0.02) \\
6.7 \pm 0.3(50 \pm 2)\end{array}$ \\
\hline $\mathrm{Pa}_{\mathrm{O}_{2}}-\mathrm{kPa}(\mathrm{mm} \mathrm{Hg})$ & $3.3 \pm 0.27(25 \pm 2)$ & $2.9 \pm 0.27(22 \pm 2)$ \\
\hline Base excess $(\mathrm{mmol} / \mathrm{l})$ & $-3.9 \pm 0.9$ & $-5.2 \pm 1$ \\
\hline
\end{tabular}

Two experiments were done on each sheep, the order being determined randomly for each animal. The first experiment consisted of a 30minute control period followed by an infusion of nitroglycerin sufficient to lower maternal mean arterial pressure by 30 per cent for 15 minutes. The nitroglycerin solution was freshly prepared by dissolving 25 tablets of $0.4 \mathrm{mg}$ in $100 \mathrm{ml}$ of 0.9 per cent saline to give a final concentration of $1 \mu \mathrm{g} / \mathrm{ml}$. The mean dose given was $113 \mu \mathrm{g}$. At the end of both the control and experimental periods maternal and foetal cardiovascular parameters were noted and blood samples were taken for measurement of maternal and foetal blood gases and nitroglycerin levels.

In the second experiment, similar measurements were made following a 30-minute control period, after an infusion of noradrenaline sufficient to rise maternal mean arterial pressure by 25 per cent for 15 minutes and after an intusion of nitroglycerin sufficient to lower maternal mean arterial pressure to control levels for 15 minutes while maintaining the previously established constant infusion of noradrenaline. Cardiovascular parameters were allowed to return to control values at the termination of all experiments to ensure that the preparation had not deteriorated.
Plasma nitroglycerin levels were measured using gas liquid chromatography with electron capture detection, following extraction of blood samples with $n$-pentane. Blood gas measurements were corrected for temperature and were done with an ABL-2 blood gas analyzer (Radiometer, Copenhagen). Statistical analysis was accomplished using Student's t-test for paired data and correlation analysis. ${ }^{6}$

\section{RESULTS}

In normotensive animals, nitroglycerin lowered maternal mean arterial pressure by 31 per cent without a significant change in heart rate (Table I). There was a concomitant 42 per cent depression of uterine blood flow and a lowering of maternal $\mathrm{Pa}_{\mathrm{O}_{2}}$. In the foetus, there were no significant changes in cardiovascular or acid-base parameters during the infusion of nitroglycerin (Table II).

Animals made hypertensive with noradrenaline exhibited a 24 per cent increase in mean arterial pressure along with a 24 per cent decrease in maternal heart rate (Table III). Uterine blood flow was decreased by 43 per cent, but maternal acid-base values were not significantly altered. 


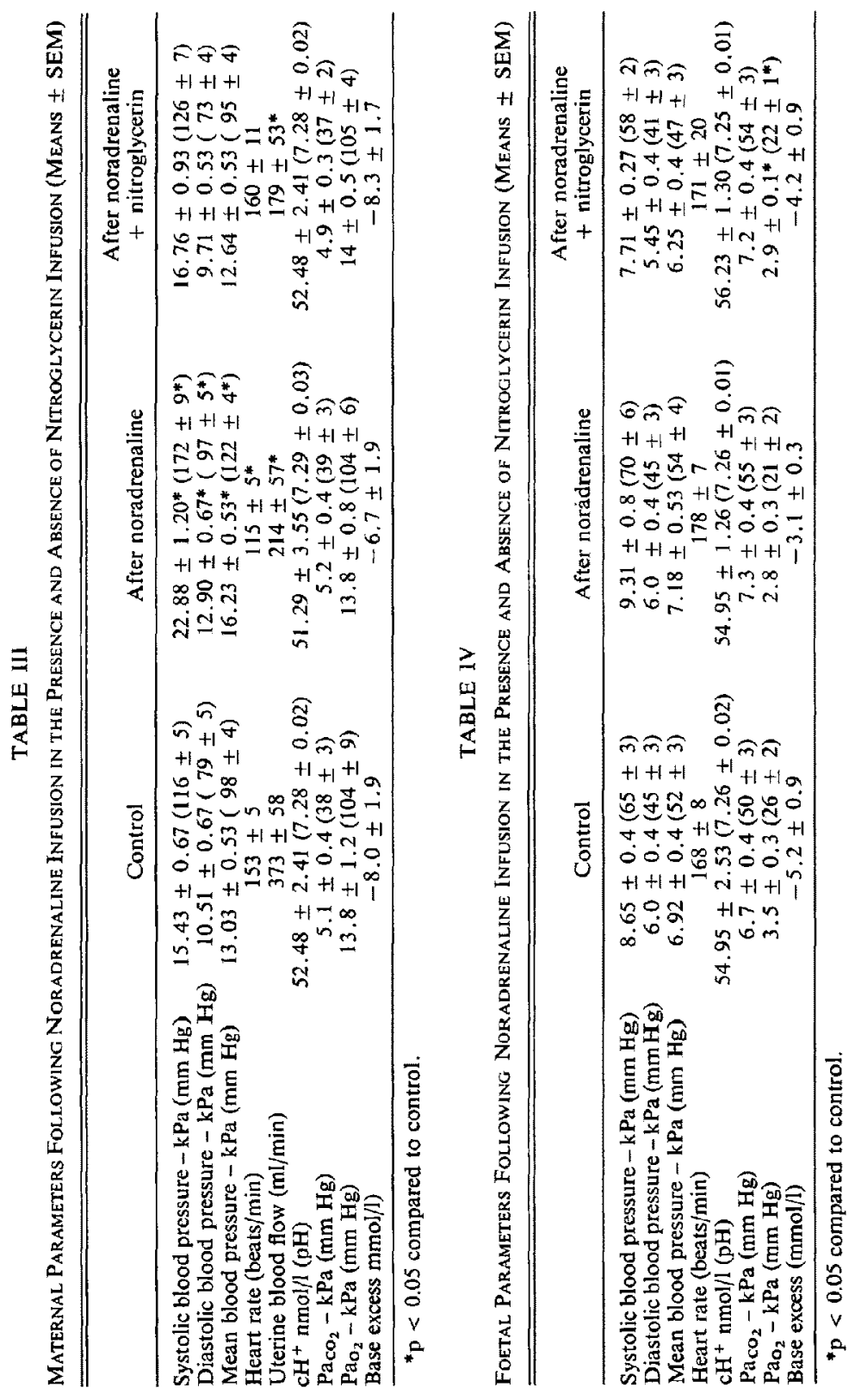


TABLE $V$

Nitroglycerin Levels (Means \pm SEM)

\begin{tabular}{lc}
\hline \hline \multicolumn{1}{c}{ Sample site } & Plasma NG (ng/ml) \\
\hline Maternal vein & $5.3 \pm 1.6$ \\
Maternal artery & $40.7 \pm 17.5$ \\
Foetal artery & $1.7 \pm 0.7$ \\
Foetal/maternal artery & $0.04 \pm 0.007$ \\
\hline
\end{tabular}

Noradrenaline infusion had no effect on foetal cardiovascular parameters (Table IV).

Treatment of the hypertension with nitroglycerin returned maternal blood pressure and heart rate to control levels (Table III). However, there was a further reduction in uterine blood flow to approximately half that of control values. The only significant change in foetal homeostasis was a reduction in $\mathrm{Pa}_{\mathrm{O}_{2}}$ when compared to control values (Table IV).

Nitroglycerin was readily detected in both maternal arterial and venous samples. It was also detected in all but two individual foetal samples. Nitroglycerin levels measured in samples from the same site did not differ significantly, regardless of whether nitroglycerin was used alone or in the presence of noradrenaline. Therefore, the data from the two groups were pooled (Table V). An attempt was made to correlate the dose of nitroglycerin infused with the nitroglycerin levels measured at the three sample sites and with the foetal artery to maternal artery ratio. The only significant correlation was between nitroglycerin dose and maternal venous levels $(r=$ $0.657, \mathrm{n}<0.005$ ).

\section{Discussion}

This study was designed to assess the cardiovascular effects of nitroglycerin and its effects on foetal well-being, its possible utilization in the treatment of gestational hypertension and its ability to cross the placental barrier.

In normotensive animals nitroglycerin produced a fall in uterine blood flow but no adverse effects on the foetus were demonstrable. The fall in uterine blood flow following hypotension is consistent with the concept that, under resting conditions, the pregnant uterine vasculature is maximally dilated and thus responds to a fall in perfusion pressure by a reduction in blood flow. ${ }^{7}$

The acute hypertension produced by noradrenaline infusion is similar to the hypertension of preeclampsia only in so far as the rise in blood pressure is not a consequence of chronic vascular changes, as in essential hypertension. Noradrenaline infusion also results in diminished uterine perfusion, which is an outstanding feature of preeclampsia. This hypertensive sheep model does not, of course, have several of the other pathological features of preeclampsia such as placental infarction and renal changes, and hence all results must be interpreted with caution. The reduction of uterine blood flow in response to noradrenaline infusion is in line with previous studies which have shown that, with $\alpha$ adrenergic vasopressors, the increase in perfusion pressure is more than offset by an increase in uterine vascular resistance. ${ }^{8.9}$

Nitroglycerin produced rapid and effective treatment of the hypertension with no changes in acid-base status. It is somewhat surprising that a further fall in uterine blood flow occurred when the hypertension was corrected.

In a recent study using the same model Wheeler, et al. ${ }^{10}$ demonstrated a similar 42 per cent reduction in uterine blood flow when mean arterial pressure was increased by 22 per cent. Lowering of the blood pressure with nitroglycerin, however, improved uterine blood flow to 25 per cent below control. The difference between our findings is probably due to the fact that Wheeler, et al. ${ }^{10}$ made their measurements in the awake unanaesthetized sheep whereas our study was in animals under light anaesthesia.

There was little evidence of deterioration in foetal well-being in spite of a reduction of uterine blood flow of up to 50 per cent. This is a finding which has been reported by other workers using the same model. ${ }^{11}$ Although the healthy sheep foetus can tolerate transient depression of uterine blood flow of a considerable magnitude, this may not be the case when one considers a foetus subjected to chronic uteroplacental insufficiency and, once again, any extrapolation to the human situation must be extremely cautious.

The low levels of nitroglycerin detected in foetal arterial blood when compared to maternal levels may be due to poor placental transfer, to widespread binding at non-active receptor sites or to differences between maternal and foetal binding. Needleman, Lang and Johnson ${ }^{12}$ have shown that there is rapid metabolism of nitroglycerin in animal and human liver by reduced glutathione and this may account for the low arterial levels in the foetus. Comparison of umbilical arterial and venous blood levels will be required to elucidate this question. Nevertheless, the levels of nitroglycerin detected in foetal arterial 
blood were not associated with hypotension in the foetus, or with significant changes in heart rate.

The only other agents with rapid onset, short duration and ease of titratability currently available for treatment of preeclampsia are sodium nitroprusside and trimetaphan. Nitroprusside has the potential to produce cyanide toxicity ${ }^{13}$ and in pregnant ewes it has been shown to cross the placenta freely with lethal consequences to one group of foetuses. ${ }^{14}$ Trimetaphan has the disadvantages of tachyphylaxis and histamine release. Its placental transfer and possible adverse effects on the foetus have not been studied. Therefore, we feel that nitroglycerin merits further evaluation for limited use in the situation where maternal well-being is seriously threatened.

\section{ACKNOWLEDGEMENTS}

The nitroglycerin assays were done by Dr. Philip L. Stetson of the Upjohn Center for Clinical Pharmacology at The University of Michigan Medical Center.

\section{REFERENCES}

1. Prys-Roberts, C., Greene, L.T., Meloche, R. \& Fö̈X, P. Studies of anaesthesia in relation to hypertension II. Haemodynamic consequences of induction and endotracheal intubation. Brit. J. Anaesth. 43: 531 (1971).

2. Boulos, B.M., Davis, L.E., Almond, C.H. \& JACKSON, R.L. Placental transfer of diazoxide and its hazardous effect on the newborn. J. Clin. Pharmacol. 11: 206 (1971).
3. Perkins, R.P. Diazoxide in treatment of severe preeclampsia and hypertensive encephalopathy. Am. J. Obstet. Gynecol. 126: 296 (1976).

4. Kaplan, J.A., Dunbar, R.W. \& Jones, E.L. Nitroglycerin infusion during coronary-artery surgery. Anesthesiology 45: 14 (1976).

5. Chestnut, J.S., Albin, M.S., Gonzalezabola, E., Newfield, P. \& Maroon, J.C. Clinical evaluation of intravenous nitroglycerin for neurosurgery. J. Neurosurg. 48: 704 (1978)

6. Batson, H.C. An Introduction to Statistics in the Medical Sciences. Minneapolis: Burgess (1956).

7. Greiss, F.C. JR. Pressure-flow relationship in the gravid uterine vascular bed. Am. J. Obstet. Gynecol. 96: 4I (1966).

8. GReiss, F.C. JR. \& VAN WILKES, D. Effects of sympathomimetic drugs and angiotensin on the uterine vascular bed. Obstet. Gynecol. 23: 925 (1964).

9. Ladner, C., Brinkman, C.R. III, Weston, P. \& AsSALI, N.S. Dynamics of uterine circulation in pregnant and nonpregnant sheep. Am. J. Physiol. 218:257(1970).

10. WHEELER, A.S., JAMES, F.M., GReISS, F.C., Meis, P.J., Rose, J.R., Fishrurne, J.J. \& DEWAN, D.M. Nitroglycerin and the uterine vasculature in gravid ewes. Anesthesiology 5/: S291 (1979).

11. Ralston, D.H., ShNider, S.M. \& DeLorimier, A.A. Effects of equipotent ephedrine, metaraminol, mephentermine and methoxamine on uterine blood flow in the pregnant ewe. Anesthesiology 40: 354 (1974)

12. Needleman, P., Lang, S. \& Johnson, E.M. Organic nitrates: relationship between biotransformation and rational angina pectoris therapy. J. Pharmacol. Exp. Ther. 181: 489 (1972).

13. JACK, R.D. Toxicity of sodium nitroprusside. Brit. J. Anaesth. 46: 952 (1974).

14. Naulty, N.S., Cefalo, R. \& Ronkey, F.L. Placental transfer and fetal toxicity of sodium nitroprusside. A.S.A. Abstracts, 543 (1976).

RÉSUMÉ

Les effets cardiovasculaires et le niveau sanguin maternel et foetal de la nitroglycérine ont été étudiés chez la brebis normotensive et hypertensive. Bien que la nitroglycérine ait causé une diminution du débit sanguin utérin à la suite de la baisse de la tension artérielle, on n’a pu constater que peu ou pas d'effets nocifs sur le foetus. La nitroglycérine a été détectée dans tous les échantillons de sang artériel foetal à l'exception de deux et le rapport entre le sang foetal et maternel n'a été que de 0.04. La nitroglycérine mérite une évaluation plus approfondie pour le traitement de la crise hypertensive de la parturiente pré-èclamptique. 